\title{
LITERARY PERSPECTIVES IN THE SEPTUAGINT OF PROVERBS
}

\author{
Johann Cook \\ Department of Ancient Studies \\ Stellenbosch University
}

\begin{abstract}
This contribution demonstrates that the person(s) responsible for the Septuagint of Proverbs employed literary perspectives on different levels. He took the broader picture of the whole of the book into consideration in his rendering of it. Hence the statement in Proverbs 1 verse 1 concerning the Proverbs of Solomon is taken seriously by him. He thus removes any references to other Proverbs. He moreover rewrites some sayings based upon a different understanding of these passages. Finally, literary perspectives are incorporated on various levels. The story with its literary nuances and not the individual lexeme was important to this translator.
\end{abstract}

\section{Introduction}

There are scholars who tend to think that the Greek translation of the Hebrew Bible is an ad hoc and hence a wooden rendering that is of limited use for an understanding of the Bible.' This may be true of the more literal or rather literalistic translations such as the book Ecclesiastes (Cook 1998), but it does not hold true for the more interpretative books, Proverbs and Job. The fact that these books are part of the corpus of wisdom literature surely impacts upon their being rendered in a more literary way.

In this contribution I intend to demonstrate that the person(s) responsible for the Septuagint of Proverbs had a creative, literary approach towards the parent text. This can be observed on various levels. Firstly, the translator took seriously the broader picture of the whole of the book. Secondly, he had a different understanding from the Massoretic text of passages and he consequently rewrote them. Thirdly, literary perspectives are incorporated on more than one level - stylistic considerations, inter alia, played a role in the translation.

\section{Methodological Issues}

The Septuagint version of Proverbs has its own unique problems, one being that the Old Greek of this book has not yet been determined exhaustively. ${ }^{2}$ This naturally complicates the discussion of the mentioned literary perspectives, since we are interested in the views located in the Old Greek text. This can be demonstrated in connection with Proverbs 11 that will be discussed below. The pocket edition of Rahlfs has no equivalent for some strophes. This applies, for example, to verse 4 where both cola are omitted. In verses 10 and 11 one stich has no equivalent in the LXX. There are, however, also examples where LXX has added stichs, for example, in verse 16. The problem is that this edition is based upon a few of the major mss only and does not represent the Old Greek text consistently.

Another important issue is that this unit exhibits a rather free translation technique and hence one would logically expect more interpretation and creativity than in a more literal

1. The LXX has in the past been deemed almost exclusively relevant for text-critical purposes.

2. In my monograph on this translated unit I have reconstructed the OG of a number of chapters (Cook 1997). Peter Gentry has been allocated the task of preparing this book for the Göttingen edition. 
rendering. I have demonstrated that the approach of the person(s) responsible for this unit should be defined as one of diversity and unity (Cook 2001a:197). This definition is based upon studies of the way the parent text was rendered on a micro, lexical level, as well as on a macro level. In demonstrating to what extent the translator actually applied literary perspectives in this book, I commence with the latter.

\section{The Broader Picture}

\subsection{The Introduction to LXX Proverbs}

The translator adopted a literary approach towards the parent text, because he worked contextually, taking smaller and larger contexts into consideration when translating. The first indication of this is already found in the opening chapter. It contains numerous pluses and minuses compared to MT as well as stylistic and literary perspectives (Cook 1997:44f) - a prominent one being verse 7, which contains two more stichoi than the Hebrew.

MT:

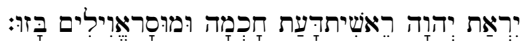

The fear of the Lord is the beginning of knowledge; fools despise wisdom and instruction.

LXX:

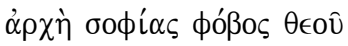

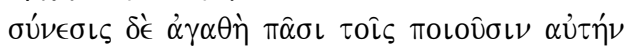

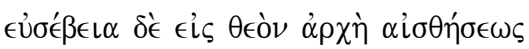

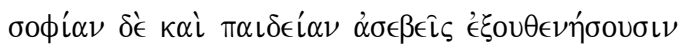

The beginning of wisdom is the fear of God,

and understanding is good for all those who practice it;

and piety unto God is the beginning of perspective,

the impious, however, will despise wisdom and instruction.

In the Festschrift for Albert Pietersma (Cook 2001) I argued that all four stichoi should be attributed to the translator and that he actually took over, intertextually, two of the stichoi ( $a$ and $b$ ) from Ps 110(111):10. This was done in order to make a paradigmatic statement about the true essence of wisdom, which in turn acts as an introduction to the whole of this book. This is done in order to underline what - in the mind of the translator - is the essence of wisdom. In the light of the whole of the book it is clear that the translator intends to remind the reader that all the person who wants to become wise ("wiser" verse 5) needs are

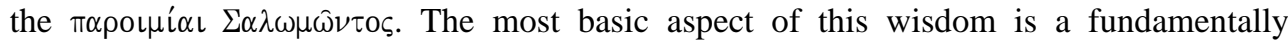
religious concept, the fear of God (фóßoৎ $\theta \in 0 \hat{)}$ ). The implication of this is that no specific form of wisdom, no speculative or even esoteric knowledge ${ }^{3}$ is fundamental to knowledge.

That the person(s) responsible for this unit indeed takes into account the rest of the book is clear from the way he deals with other proverbs that are referred to in the Hebrew.

3. I have criticised the interpretation by Sandelin (1986) that LXX Proverbs 9 actually contains references to Greek mysteries (Cook 1997:247-296). 


\subsection{Proverbs of Solomon}

The second example of the literary approach of this translator is the way that he deals with references to the proverbs of Solomon. Proverbs 1 verse 1 states that these are the Proverbs of Salomon, son of Dauid and the statement is taken seriously by the translator pertaining to the whole book. In Chapter 10 verse 1 MT reads:

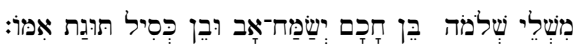

The proverbs of Solomon. A wise son makes a glad father, but a foolish son is a mother's grief.

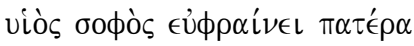

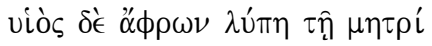

A wise son makes a father glad;

but a foolish son is a mother's grief.

There is no reference to the phrase שישל which, when evaluated in the light of the whole book, is natural since to the translator it was logical that there is only one collection - in this book at least - of Solomonic proverbs.

Another passage testifies to this tendency. In Chapter 25 verse 1 the Hebrew refers to other proverbs of Solomon.

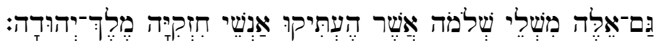

These also are proverbs of Solomon which the men of Hezekiah, king of Judah, copied.

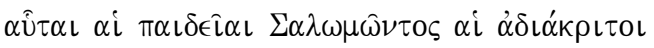

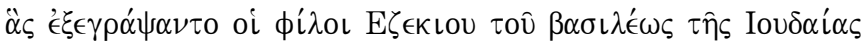

These are the miscellaneous ${ }^{4}$ instructions of Solomon,

which the friends of Ezekiah king of Judea copied.

Thus it would seem that the translator is at pains to demonstrate that there is only one collection of Solomon's sayings. This is underscored by the way he deals with other Proverbs in addition to Solomon's that are mentioned in this book.

\subsection{Proverbs other than Solomon's}

A characteristic of the freedom with which the book is rendered is the deliberate omission of references to names of wisdom teachers other than Solomon. In chapter 30 the name of Agur and in 31 that of Lemuel are omitted.

A. Agur

Proverbs 30 verse 1 reads as follows:

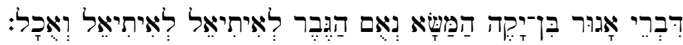

The words of Agur son of Jakeh of Massa. The man says to Ithiel, to Ithiel and Ucal:

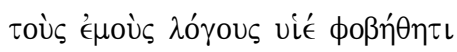

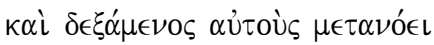

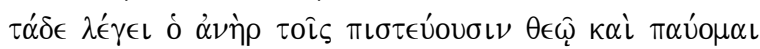

My son, fear my words,

and repent when you receive them;

4. Underling and italics indicate additions and/or interpretations. 
Thus says the man to those who believe in God: Now I stop.

As can be observed, the whole verse is practically rewritten and any reference to Agur is removed. As a matter of fact Ithiel and Ucal are also not referred to.

\section{B. Lemuel}

The same applies to Proverbs 31 verses 1 and 4, where the name of Lemuel does not appear in the Septuagint. Verse 1 reads:

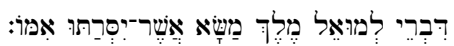

The words of Lemuel, king of Massa, which his mother taught him:

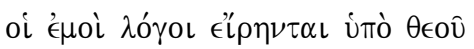

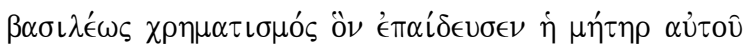

My words have been spoken by God,

the oracular answer of a king, whom his mother instructed.

The reading למוּאל could certainly be connected to God on account of a different understanding of the unpointed text. However, it is clear that this verse has been interpreted. This is especially evident in the light of the next verse.

Verse 4 reads:

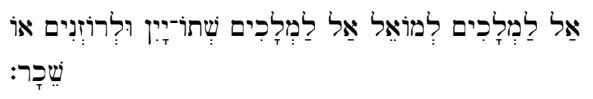

It is not for kings, O Lemuel, it is not for kings to drink wine, or for rulers to desire strong drink;

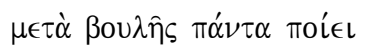

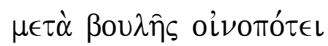

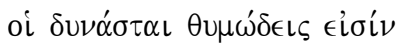

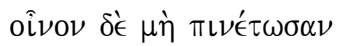

Do everything with counsel;

drink wine with counsel.

Those in power are wrathful;

but let them not drink wine,

Clearly the reference to Lemuel is omitted. The underlined passages, moreover, give an indication of the extent to which these passages have been interpreted.

\subsection{Larger adaptations on the basis of literary considerations}

The larger context is also taken into consideration by the translator in the conspicuous difference of the order of chapters from chapter 24 onwards. One example occurs in chapter 31 , which precedes chapter 25 . In my view this difference is the result of deliberate adaptation by the translator on account of literary/thematic considerations.

Proverbs 31 in the Hebrew can be divided into two parts. The first contains the instruction of Lemuel to which I have referred above. The second is the acrostic in verses 10-31. The central theme of the first part is the king. Hence in verse 9 the king is ordered to:

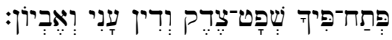

Open your mouth, judge righteously, maintain the rights of the poor and needy. 


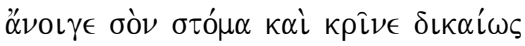

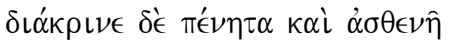

Open your mouth and judge justly

and plead the cause of the poor and weak.

The first 8 verses in chapter 25 also refer to the king, as can be seen from the passage concerning the miscellaneous proverbs copied by the friends of the king of Judah which I discussed above.

I am thus of the opinion that the translator deliberately changed the order of these chapters on the basis of literary/thematic considerations. In the Festschrift for Emanuel Tov (Cook 2003:610) I argued that some of the other major adaptations are the result of what I have called contrastive considerations. The acrostic in Proverbs 31:10-32 was, in my view, deliberately linked to Proverbs 29 , since there is a contrast between these passages. All these adaptations bear witness to the freedom with which the translator approached his parent text.

\section{Rewriting of Passages}

Proverbs 1 and 2 contain various examples of passages that were understood differently from the Hebrew by the translator. As I indicated already the larger context is taken into account by the translator and he does not translate in an ad hoc manner. In conjunction with the MT, Chapter 1 is divided into three parts by the translator. In the third part (verses 2033) the translator follows his own interpretation (Cook 1997:83). He had a different view on verse 32, which has implications for the macro-structure of practically the whole passage. ${ }^{5}$ Three passages are significant in this regard:

Verse 32

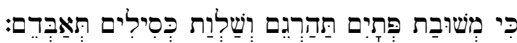

For the simple are killed by their turning away, and the complacence of fools destroys them;

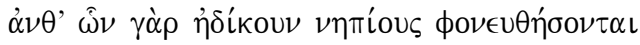

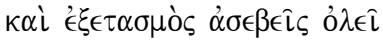

For because they wronged the innocent they will be slain, and an inquiry will ruin the ungodly.

Verse 28:

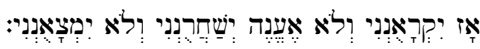

Then they will call upon me, but I will not answer;

they will seek me diligently but will not find me.

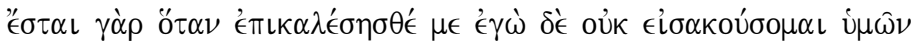

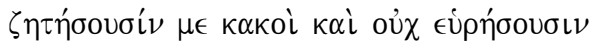

For when you call me I will not listen to you,

the wicked will seek me but they will not find.

5. Cf. Cook, Septuagint of Proverbs, 90-98. 
And verse 22:

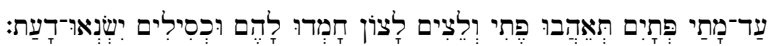

How long, O simple ones, will you love being simple?

How long will scoffers delight in their scoffing

and fools hate knowledge?

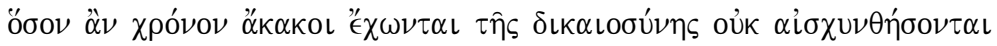

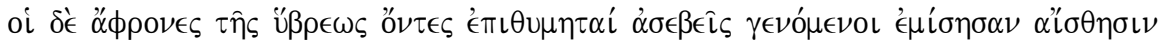

As long as the innocent hold on to righteousness they will not be ashamed,

but the foolish being desirers of hubris, after becoming ungodly they hate knowledge...

As can be seen, the translator again took into account the larger context. Hence he made a

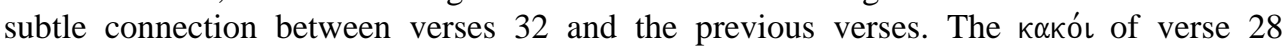
onwards, which in the final analysis goes back to and also includes the "fools" (oi " $\alpha \rho \circ \nu \in \varsigma$ ) of verse 22, are made the subjects of those who wronged the innocent. They are then killed and not the innocent as stated by MT. This interpretation can only be arrived at if the whole passage is read and not just the individual words in the sentences.

In this instance the Greek translator followed the syntax of the Hebrew to some extent, but expressed the individual clauses in a typically Greek linguistic manner (cf. verse 22). In some instances he does bring about nuanced changes in order to deliberately express specific meanings. As demonstrated above, he did this in verses 22, 23 and 32. Here he has clearly structured his translation in order to emphasise a religious theme: the contrast between the good and the bad. Religious considerations thus have an impact on a syntactic level as well. This applies to Proverbs 2 as well, where the addition of the particle $\hat{\omega}$ in verse 13 actually acts to divide the chapter into two parts, describing two realms: the good (verses 1-12) and the bad (verses 13-33).

The translator adopts the same approach in Proverbs 11. There are numerous examples of interpretation on the basis of a different understanding of passages. Religious considerations clearly also played a directive role in this regard. These are, however, sometimes combined with literary considerations.

The whole chapter contains contrasts in the Hebrew; a false balance over against an accurate one (verse 1); pride and humbleness (verse 2); the upright and the impious clearly dominate in this passage (verses $3,5,6,7,8,9,10,11,18,19,21,23,31$ ); the merciful and the merciless (verse 17).

The translator firstly adds explicative renderings with literary effect. In verse one weights are typified as just weights. In verse two the Greek word $\sigma \tau{ }^{\prime} \mu \alpha$ is added:

Where pride enters, there will also be disgrace;

but the mouth of the humble meditates wisdom.

In verse 16 the explicative addition for her husband in connection with the gracious woman has probably been done in the light of chapter 31 . In verse 18 the gains of the impious are described as unrighteous works. In the next verse someone who is steadfast in righteousness is called a righteous son. Also in verse 20 the translator interprets when he talks about crooked ways instead of crooked minds. In verse 27 the translator understood the passage "whoever diligently seeks good seeks favour" somewhat differently as "He who devises good seeks good favour". Finally, in verses 30 and 31 exegetical renderings are used in order to provide the translation with nuances. The cutting off of unrighteous lives is done untimely in verse 30 . The addition of $\mu$ ó $\lambda \iota \varsigma$ (scarcely) in connection with the 
saving of the righteous has no foundation in the Hebrew. These nuanced interpretations surely enhance the literary quality of this chapter.

In addition to these smaller exegetical renderings that are, inter alia, based upon literary considerations, there are also more extensive rewriting of passages. The first occurs in verse 7 , where the MT mentions only the wicked and the godless, which are synonyms. However, the Septuagint then interprets freely by creating a contrast in that the wicked man

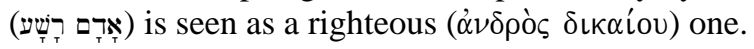

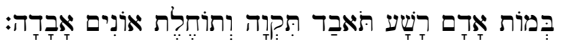

When the wicked die, their hope perishes, and the expectation of the godless comes to nothing.

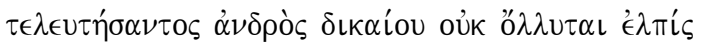

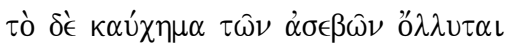

When a righteous person dies hope does not perish; but the boast of the impious perishes.

The translator clearly had the intention to interpret rather freely. It would seem as if the changes brought about are not rooted in the Hebrew. The negative particle oúk clearly has no equivalent in the Hebrew. In line with his general approach, he deliberately created a contrast in the Greek, namely a contrast between a righteous person and the impious. Once he had done this, he simply had to adapt the passage by adding the negative particle oủk.

I have demonstrated that the contrasting which appears in the LXX of Proverbs to a larger extent than it does in the Hebrew is a characteristic of this translator (Cook 1997a). An example is found in verse 16:

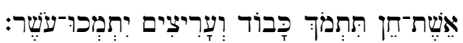

A gracious woman gets honour, and violent men get riches.

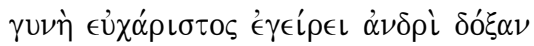

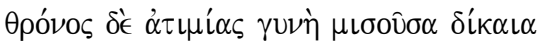

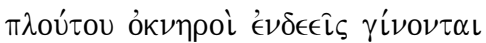

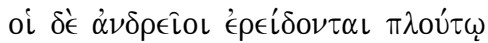

A gracious wife procures honour for her husband,

but a seat of dishonour is a woman who hates justice.

The deficient shrink from wealth,

but the diligent support themselves with wealth.

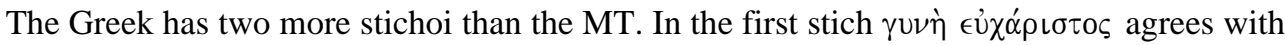
אישתחיח The second stich contains a contrast to this gracious woman, namely "the woman

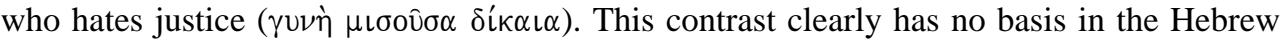
and must be seen as the work of the translator.

\section{Literary, Stylistic Perspectives}

Stylistic perspectives had an interplaying influence on the translator of Proverbs. In chapter 1 verses 1-7, a passage to which I have referred to above, stylistic features abound. Greek particles are applied creatively. The particle $\tau \epsilon$ is used in the first 6 verses for stylistic effect. It is used extremely sparsely in the whole book of Proverbs, for instance, in chapter 8 verse 13, which I will discuss below. The application of explicative additions in order to express the meaning of the Hebrew also appears in this context. The adjective $\nu$ '́⿴\zh11 in verse 
4 is added to $\pi \alpha \iota \delta\llcorner$ . Word combinations are also used, for example in verse 3 where

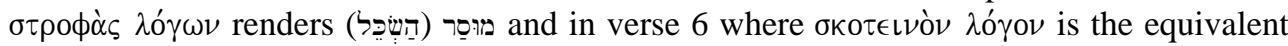
for מִלִיָָה. Later in the chapter two word combinations are used in order to contrast two

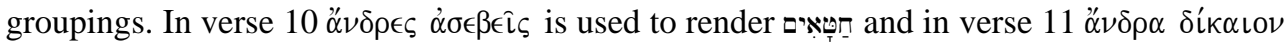
as equivalent of נִָּ.

Rhyme, moreover, was taken into account by the translator. In Proverbs 1 verses 2 and

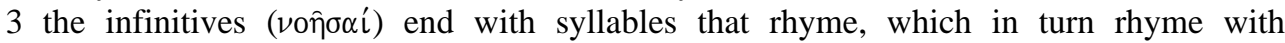
$\pi \alpha \rho o \iota \mu i \alpha \iota$ (Cook 1997).

A similar example is found in Proverbs 8 verse 13, where style clearly has an interplaying role.

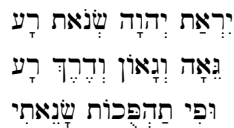

The fear of the Lord is hatred of evil.

Pride and arrogance and the way of evil and perverted speech I hate.

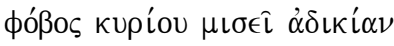

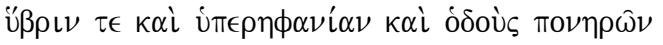

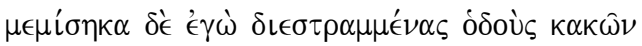

The fear of the Lord hates injustice,

also pride and arrogance and the ways of the wicked,

yes it is I, who hates the perverse ways of the evil.

To me it is clear that the translator - on the basis of stylistic considerations - interpreted

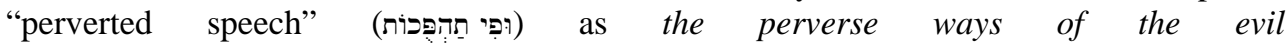

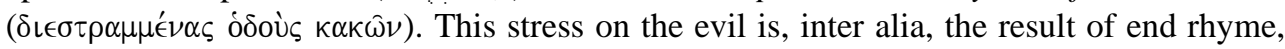

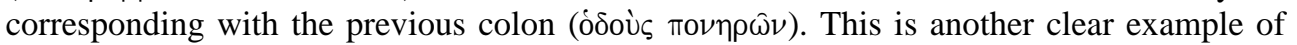
the literary competence of this translator.

\section{Conclusion}

From the above it should be clear that the translator of the Septuagint version of Proverbs had an excellent education in Hebrew and Greek. Literary perspectives were important to him and he incorporated them into his translation on various levels. To this translator the broader picture, the larger context, was determinative, i.e. the story with its literary nuances were given a high priority and not the individual lexeme. In the final analysis these perspectives were applied in service of religious considerations. These religious views, I have argued, are not those found in Hellenistic circles such as the Stoa (Gerleman 1950), or in Platonism (Hengel 1973:292-293 and Deist 1988:165), nor in the mystery religions (Sandelin 1986:76), but in the more conservative Jewish circles that were attempting to prevent Judaism from being overwhelmed by Hellenistic Greek religious interpretations (Cook 1997:320 and 1999). 


\section{BIBLIOGRAPHY}

Attridge, HW (et al.) 1990. Of Scribes and Scrolls, Studies on the Hebrew Bible,

Intertestamental Judaism, and Christian Origins Presented to John Strugnell, Lanham, Maryland.

Cook, J 1997a. Contrasting as a Translation Technique, in: Evans CA \& Talmon S (eds.), 403-414.

Cook, J 1997. The Septuagint of Proverbs - Jewish and/or Hellenistic Proverbs? (concerning the Hellenistic colouring of LXX Proverbs). Vetus Testamentum Supplementum 69, Leiden: Brill.

Cook, J 1998. Aspects of the relationship between the Septuagint versions of Kohelet and Proverbs, in: A Schoors (ed.), Qohelet in the context of Wisdom. BETL CXXXVI, Peeters: Leuven, 481-492.

Cook, J 1999. The Law of Moses in Septuagint Proverbs. Vetus Testamentum 49/3, 448461.

Cook, J 2001a. Ideology and translation technique: Two sides of the same coin?, in: Sollamo, R \& Sipilä, S (eds.), 195-210.

Cook, J 2001. Intertextual relationships between the Septuagint of Psalms and Proverbs, in: Hiebert, RJV, Cox, CE \& Gentry, PJ (eds.), The Old Greek Psalter. Studies in honour of Albert Pietersma. Sheffield Academic press: Sheffield, 218-228.

Cook, J 2003. The Greek of Proverbs - evidence of a recensionally deviating Hebrew text? in: Paul et al. (eds.), 605-618.

Cook, J (forthcoming). Theological/ideological Tendenz in the Septuagint - LXX Proverbs: a case study, in: Sipilä, S (ed.), XI Congress of the International Organization for Septuagint and Cognate Studies: Basel, 2001, (Septuagint and Cognate Studies), Atlanta, GA.

Deist, FE 1988. Witnesses to the Old Testament. NGKB: Pretoria.

Evans CA \& Talmon S (eds.) 1997a. From Tradition to Interpretation: Studies in Intertextuality in Honor of James A. Sanders. Leiden: Brill.

Fernández Marcos, N 2000. The Septuagint in context. Introduction to the Greek version of the Bible. Leiden-Boston-Köln: Brill.

Gerleman, G 1950. The Septuagint Proverbs as a Hellenistic Document. OTS 8, 15-27.

Gerleman, G 1986. Studies in the Septuagint. III. Proverbs. Lunds Universitets Årsskrift. N.F. Avd. 1 Bd 52. Nr 3, Lund.

Hengel, M 1973. Judentum und Hellenismus. Studien zu ihrer Begegnung unter besonderer Berücksichtigung Palästinas bis zur Mitte des 2.Jh.s v.Chr. Mohr: Tübingen.

Paul, SM, Kraft, RA, Schiffman, RL and Fields, WW (eds.), EMANUEL - Studies in the Hebrew Bible, Septuagint and Dead Sea Scrolls in honor of Emanuel Tov. Brill: Leiden-Boston.

Sollamo, R \& Sipilä, S (eds.) 2001. Helsinki perspectives on the translation technique of the Septuagint. Göttingen: VandenHoeck \& Ruprecht.

Tov, E 1990. Recensional Differences between the Masoretic Text and the Septuagint of Proverbs, in: Attridge (et al.), 43-56. 
Tov, E \& Wright, BG 1985. Computer-Assisted Study of the Criteria for Assessing the Literalness of Translation Units in the LXX. Textus 12, 149-187. 